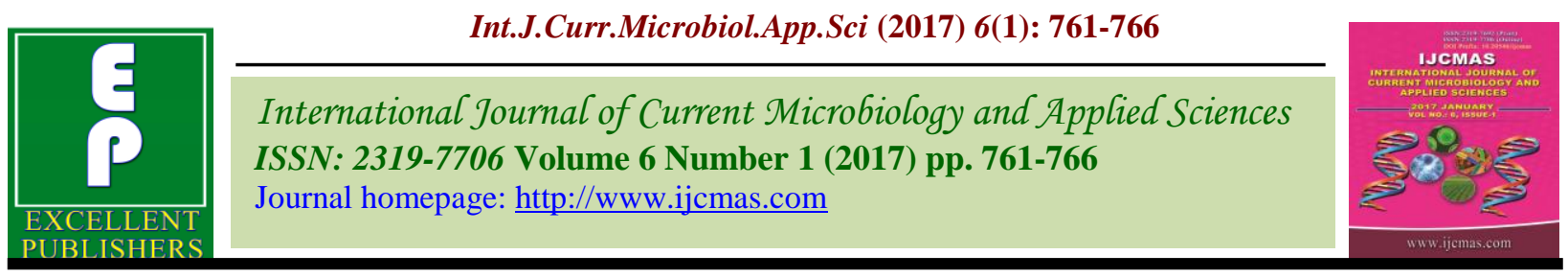

Original Research Article

http://dx.doi.org/10.20546/ijcmas.2017.601.091

\title{
Diagnostic Utility of serum C - Reactive Protein in Rhinosinusitis and its Role in Reducing Antibiotic Use
}

\author{
S. Gowri* and Kanaga Priya Muthiah \\ Department of Microbiology, Tirunelveli Medical College, Tirunelveli, India \\ *Corresponding author: gowriravanan@gmail.com
}

\begin{tabular}{|c|c|}
\hline & A B S T R A C T \\
\hline $\begin{array}{l}\text { K e y w o r d s } \\
\text { Acute rhino } \\
\text { sinusitis, CRP, } \\
\text { ESR, } \\
\text { Rapid test, } \\
\text { antibiotics. }\end{array}$ & \multirow{3}{*}{$\begin{array}{l}\text { This study was undertaken to evaluate the utility of serum C-reactive protein in the } \\
\text { diagnosis of bacterial sinusitis and its role in reduction of antibiotic use in case of viral } \\
\text { sinusitis. A total of } 100 \text { blood samples were collected from patients with clinical } \\
\text { diagnosis of acute rhino sinusitis in the age group } 15-65 \text { years attending Outpatient } \\
\text { Department of E.N.T. Semi quantitative determination of serum C -reactive protein } \\
\text { was done by latex agglutination method (Span diagnostics) as per the manufacturer's } \\
\text { instructions. Among study population, CRP was normal in } 66 \text { (66\%) patients and the } \\
\text { same was increased in } 34(34 \%) \text { patients. Among the CRP elevated group (34), } 6 \\
\text { persons had CRP levels more than } 0.6 \mathrm{mg} / \mathrm{dl} \text { to } 1 \mathrm{mg} / \mathrm{dl}, 14 \text { persons had CRP levels } \\
\text { within the range of } 1.1-5 \mathrm{mg} / \mathrm{dl} \text {, and the remaining } 14 \text { persons had CRP levels more } \\
\text { than } 5 \mathrm{mg} / \mathrm{dl} \text {. The present study has elucidated the role of assay of serum CRP as a } \\
\text { marker of inflammation in sinusitis. The role of assay of serum CRP by rapid passive } \\
\text { latex agglutination method was studied and found valid. }\end{array}$} \\
\hline Article Info & \\
\hline $\begin{array}{l}16 \\
76: \\
7\end{array}$ & \\
\hline
\end{tabular}

\section{Introduction}

Sinusitis or more accurately, Rhino sinusitis is a global problem and a common disorder affecting $20 \%$ of the population (Eloy et al., 2011). The inflammation or swelling of the tissue lining the paranasal sinuses is known as sinusitis. Sinusitis is caused by allergy, viruses, bacteria and few fungi. It affects immune compromised as well as immunocompetent individuals. In India one in eight of the population is affected by sinusitis (Sunali et al., 2012). Approximately 1 in 7 or $12.5 \%$ or 31 million people in USA are affected by sinusitis each year (Pleis et al., 2008; Adams et al., 1999; Anand, 2004). Sinusitis results in the inflammation of the sinuses and cause symptoms, such as facial pain and pressure and thick greenish mucus that is discharged from the nose. The National Ambulatory Medical care Survey (NAMCS) states that sinusitis is the fifth most common diagnosis for which antibiotic is prescribed (Smith et al., 2009; Shah et al., 2005).

Sinusitis is often diagnosed clinically with little role for radiography and computerised axial tomography in early stages of the disease. A fluid level and opacification of a sinus on CT scan is $90 \%$ specific for acute bacterial sinusitis. The percentage of the finding relevant to headache on CT scans, Magnetic resonance imaging studies and electroencephalograms were $42 \%, 33.3 \%$ and 
$25 \%$ respectively. It has a high sensitivity but low specificity for demonstrating acute sinusitis. These modalities are expensive and are not present in primary care set up (McAlister et al., 1989; Low et al., 1997).

Serum C reactive protein is elevated within 24 hours of the onset of clinical illness in acute bacterial sinusitis while it will be within normal limits in viral sinusitis. Acute viral sinusitis is either extremely common or it is over diagnosed. Sinusitis less than 7 days is viral sinusitis, more than 7 days is bacterial sinusitis. Symptoms of bacterial rhino sinusitis overlap with viral rhino sinusitis, and it is difficult to distinguish between the two conditions based only on a clinical examination (Lindbaek et al., 1996; De Sutter et al., 2006). Bacterial infection of the sinuses is estimated to occur in $0.5 \%$ to $2 \%$ of cases of viral Upper Respiratory tract Infections in adults and $6 \%$ to $13 \%$ in children. Irrational use of antibiotics for the treatment of viral sinusitis leads to drug resistance in due course (Ray et al., 1999).

Microbial lipopolysaccharides such as endotoxins can stimulate macrophages to release IL-1 which stimulates liver to produce increased amounts of acute phase proteins such as C-reactive protein, the concentrations of which can rise over 1000 fold soon after the entry of microbial pathogens. One of the best characterised acute phase proteins is $\mathrm{C}$ reactive protein.

It rises within 2 hours of the onset of inflammation up to 50,000 fold and peaks at 48 hours. Increased levels of CRP can be detected 6-12 hours after the onset of a bacterial infection by means of a rapid test. It is elevated in patients who have an inflammatory condition of infectious or noninfectious aetiology. Studies have shown that measurement of CRP is useful for the diagnosis of bacterial sinusitis in general practice (Lindbaek et al., 2002; Savolainen et al., 1997; Huovinen et al., 1998.).
A raised CRP level is an indicator of bacterial infection and the CRP in serum can be measured by rapid latex agglutination test, ELISA and automation methods. The rapid test or latex agglutination test has been shown to be useful for the diagnosis of bacterial sinusitis in general practice (Lars Bjerrum et al., 2004). It is a test that measures the CRP concentration in serum. Serum C-reactive protein assay by immunochromatography is cost effective and rapid, easy to perform test.

In a study by National institute of health in USA, CRP rapid test has substantial influence in the treatment of sinusitis and implementation of this test in general practice may lead to a reduction in antibiotic prescribing to patients with sinusitis. The enormous use of antibiotics has a financial impact on the health services. More importantly, it can contribute to the emergence and spread of antibiotic- resistant bacteria (Huovinen et al., 1993). It is therefore important to appropriately identify and manage this common condition

With this background this study was undertaken to evaluate the utility of serum Creactive protein in the diagnosis of bacterial sinusitis and its role in reduction of antibiotic use in case of viral sinusitis

The main aim of this study, to assay the presence of C-reactive protein in serum samples from sinusitis patients. And also to compare the serum C- reactive protein levels in viral and bacterial sinusitis.

\section{Materials and Methods}

Study place: Department of Microbiology and Department of E.N.T.

Study period: 6 months

Ethical Committee Approval: The study 
protocol was carried out after approval by the Institutional Scientific and Ethics Committee.

Specimen - Blood

Sample size: 100

\section{Study population}

Inclusion criteria Patients with clinical diagnosis of acute rhino sinusitis in the age group 15-65 years attending Outpatient Department of E.N.T was included in this study. Meticulous care was taken in obtaining patient details and same was recorded in proforma.

Exclusion criteria: Patients with sinusitis and prior antibiotic treatment for the current illness, patients with concurrent malignancies, steroid therapy and other immunosuppressive therapy.

\section{Sample collection}

Venepuncture was done under strict aseptic precautions and $2 \mathrm{ml}$ blood was collected in plain test tubes and serum was separated by centrifugation of plain blood sample at 1500 rpm for 10 minutes.

\section{Laboratory procedure}

\section{Serum C-Reactive Protein estimation}

Semi quantitative determination of serum C reactive protein was done by latex agglutination method (Span diagnostics) as per the manufacturer's instructions.

\section{Results and Discussion}

In the present study, 100 patients whose age varied from 15 years to 67 years were tested and it was found that $24 \%$ were in the age group of 15years to 25years, more number of $(46 \%)$ patients were in the age group of 25 to 35 years. Patients in the age group of 35 years to 45 years were $16 \%$ and patients in the more than 45 age group were only 14\%(Table1). Out of 100 patients, 28 (28\%) were males and $72(72 \%)$ were females.(Table-2). Among study population, CRP was normal in $66(66 \%)$ patients and the same was increased in $34(34 \%)$ patients. Out of these 34 patients with elevated CRP 10 were males and 24 were females (Table- 3). Among the CRP elevated group (34), 6 persons had CRP levels more than $0.6 \mathrm{mg} / \mathrm{dl}$ to $1 \mathrm{mg} / \mathrm{dl}, 14$ persons had CRP levels within the range of 1.1-5 $\mathrm{mg} / \mathrm{dl}$, and the remaining 14 persons had CRP levels more than $5 \mathrm{mg} / \mathrm{dl}$ (Table- 4) Among these 34 patients with elevated CRP facial tenderness over the paranasal sinuses especially maxillary sinuses was elicited in all of them. Out of the 34 patients with elevated CRP, ESR too was increased in 32 (94\%) patients (Table- 5).

In the present study, out of the 100 patients, $28(28 \%)$ were males and $72(72 \%)$ were females. There was a female preponderance. Sinusitis is diagnosed more frequently in adult women than men (Anand et al., 2004; da Lilly-Tariah et al., 2006). This was in concordance with a Nigerian study (Adoga et al., (2011). Increased susceptibility of females to asthma, chronic obstructive airway disease and rhino sinusitis may be the explanation for this (Chen et al., 2003).

In this study, serum CRP was above normal upper limit of reference interval in 34(34\%) of the patients. This is in concordance with another study where $28.7 \%$ of patients with upper respiratory tract infections were with elevated serum CRP values (Andreeva and Melbye, 2014).

In the present study, serum CRP levels were more than $5 \mathrm{mg} / \mathrm{dl}$ in $14(41 \%)$ patients only. In contrast to the study done by Hansen et al, where it was $57 \%$.This may be due to the smaller size of the study population (Hansen et al., 2000). 
Erythrocyte Sedimentation Rate (ESR) and CRP were found to be independently associated with a diagnosis of acute maxillary sinusitis. In some cases the combination of the two measurements may improve diagnostic sensitivity and specificity (Jens Georg Hansen et al., 1995). Out of the 34 patients with elevated CRP, ESR also was increased above normal limits in 32 (94\%) patients. This indicates that in sinusitis due to bacterial infections ESR is raised and it serves as a marker of inflammation. This is in accordance with the Danish study where ESR elevation was found in acute bacterial infections (Jens Georg Hansen, 2000, 2014).

Table.1 Age wise distribution of the study population

\begin{tabular}{|c|c|}
\hline $\begin{array}{c}\text { Age group } \\
\text { (in years) }\end{array}$ & No. of patients(100) \\
\hline $\mathbf{1 5 - 2 5}$ & $24 \%$ \\
\hline $\mathbf{2 5 - 3 5}$ & $46 \%$ \\
\hline $\mathbf{3 5 - 4 5}$ & $16 \%$ \\
\hline$>\mathbf{4 5}$ & $14 \%$ \\
\hline
\end{tabular}

Table.2 Gender distribution of the study population

\begin{tabular}{|c|c|}
\hline Gender & Total(100) \\
\hline Male & $28 \%$ \\
\hline Female & $72 \%$ \\
\hline
\end{tabular}

Table.3 CRP levels among the study population

\begin{tabular}{|c|c|c|c|}
\hline CRP Levels & Male & Female & Total(100) \\
\hline Elevated above normal & 10 & 24 & $34 \%$ \\
\hline Normal & 18 & 48 & $66 \%$ \\
\hline
\end{tabular}

Table.4 CRP distribution among the elevated CRP levels

\begin{tabular}{|c|c|}
\hline CRP levels & No. of Persons (n-34) \\
\hline More than 0.6 mg/dL to $1 \mathrm{mg} / \mathrm{dl}$ & 6 \\
\hline Medium level $1.1-5 \mathrm{mg} / \mathrm{dl}$ & 14 \\
\hline High level $>5 \mathrm{mg} / \mathrm{dl}$ & 14 \\
\hline
\end{tabular}

Table.5 Distribution of elevated ESR in increased CRP patients

\begin{tabular}{|l|c|c|c|}
\hline CRP levels & $\begin{array}{c}\text { Erythrocyte } \\
\text { Sedimentation Rate } \\
\text { (ESR) Normal }\end{array}$ & $\begin{array}{c}\text { Erythrocyte } \\
\text { Sedimentation } \\
\text { Rate(ESR) Elevated }\end{array}$ & Total \\
\hline Elevated above normal & 2 & 32 & 34 \\
\hline Normal & 66 & 0 & 66 \\
\hline Total & 68 & 32 & 100 \\
\hline
\end{tabular}


Deviation of nasal septum towards right or left was present in $18(53 \%)$ patients which is a significant risk factor for acquiring sinusitis. This was similar to a few other studies (Azila et al., 2011; Dua et al., 2005).

Among study population, CRP was normal in $66(66 \%)$ patients and this may due to a viral aetiology increased in $34(34 \%)$ patients. Most sinus infections are caused by viruses rather than bacteria and should not be treated with antibiotics, a common practice that contributes to the development of drugresistant "superbugs". Antibiotic treatment should be reserved for patients with moderately severe symptoms of bacterial sinusitis of greater than 10 days duration and for those with severe symptoms regardless of duration of illness (Rosenfeld et al., 2007; 2015). In conclusion, the present study has elucidated the role of assay of serum CRP as a marker of inflammation in sinusitis. Its prognostic value is more as serum CRP level would come to normal level during appropriate treatment for sinusitis .ESR test is also a contributory test in assessing the severity of inflammation and prognosis of the disease. The present study has analysed the age, gender distribution of patients with sinusitis. The role of assay of serum CRP by rapid passive latex agglutination method was studied and found valid. Testing serum CRP in acute sinusitis will reduce prescription of antibiotics for sinusitis as a routine. As this is a rapid test, time taken for performing the test is very short it facilitates an early diagnosis of either viral or bacterial sinusitis. This will also help to curtail the unnecessary use of antibiotics for a viral sinusitis as the cost of antibiotics as well as antibiotic resistance is high in the community.

\section{References}

Adams, P.F., Hendershot, G.E., Marano, M.A. 1999. Center for Disease Control and Prevention/ National Center for Health
Statistics.Current estimates from National Health Interview Survey Vital Health Stat., 10(200);1- 203.

Adoga, A.A., Ma'an, N.D. 2011. The Epidemiology and Economic Impact of Rhinosinusitis in Jos, North Central Nigeria. J. Clinic Res. Bioeth., 2: 116. doi:10.4172/2155-9627.1000116.

Anand, V.K. 2004. Epidemiology and economic impact of rhinosinusitis. Ann. Otol. Rhinol. Laryngol. Suppl., 193: 3-5.Pubmed google Scholar

Andreeva, Melbye. Usefulness of C-reactive protein testing in acute cough/respiratory tract infection: an open cluster-randomized clinical trial with C-reactive protein testing.

Azila, A., Irfan, M., Rohaizan, Y., Shamim, A.K. 2011. The prevalence of anatomical variations in osteomeatal unit in patients with chronic rhinosinusitis. Med. J. Malays., 66(3): 191-194.

Chen, Y., Dales, R., Lin, M. 2003. The epidemiology of chronic rhinosinusitis in Canadians. Laryngoscope, 113: 1199-1205.

Da Lilly-Tariah, O.B. 2006. Pattern of clinical features of chronic simple rhinosinusitis in Port-Harcourt. Niger J Clin. Pract., 9: 142146.

De Sutter, A., Lemiengre, M., Van Maele, G. et al. Predicting prognosis and effect of antibiotic treatment in rhinosinusitis.

Dua, K., Chopra, H., Khurana, A.S., Munjal, M. 2005. CT scan variations in chronic sinusitis. Indian J. Radiol. Imaging, 15(3):315-320.

Eloy, P., Poirrier, A.L., De Dorlodot, C. et al. 2011. Actual concepts in rhinosinusitis: a reviewof clinical presentations, Curr Allergy Asthma Rep., 11(2): 146-62.

Hansen, J.G., Schmidt, H., Grinsted, P. 2000. Randomised, double blind, placebo controlled trial of penicillin $\mathrm{V}$ in the treatment of acute maxillary sinusitis in adults in general practice. Scand J. Prim Health Care, 18: 44-7.

Hansen, J.G., Schmidt, H., Rosborg, J., Lund, E. 1995. Predicting acute maxillary sinusitis in a general practice population. BMJ, 311: 233-236.

Huovinen, P., Cars, O. 1998. Control of antimicrobial resistance: time for action. 
The essentials of control are already well known. BMJ, 317: 613-614.

Huovinen, P. 1993. Resistance to antimicrobial drugs - a worldwide calamity. Ann. Intern Med., 118557-561.561 [PubMed]] intervention group. BMC Family Practice 2014 15:80.

Jens Georg Hansen Acute Rhinosinusitis (ARS). Diagnosis and treatment of adults in general practice. Dan. Med. J., 61(2): B4801.

Lars Bjerrum, Bente Gahrn-Hansen and Anders, P. Munck. 2004. C-reactive protein measurement in general practice may lead to lower antibiotic prescribing for sinusitis British J. General Practice, 54, 659-662.

Lindbaek, M., Hjortdahl, P., Johnsen, U.L. 1996. Randomised, double blind, placebo controlled trial of penicillin $\mathrm{V}$ and amoxycillin in treatment of acute sinus infections in adults. BMJ, 313: 325-9.

Lindbaek, M., Hjortdahl, P. 2002. The clinical diagnosis of acute purulent sinusitis in general practice a review. Br. J. Gen. Pract., 52: 491-495.

Low, D.E., Desrosiers, M., McSherry, J. et al. 1997. A practical guide for the diagnosis and treatment of acute sinusitis. Can. Med. Assoc. J., 156: 51-4.

McAlister, W.H., Lusk, R., Muntz, H.R. Comparison of plain radiographs and coronal CT scans in infants and children with recurrent sinusitis. Am. J. Roentgenol., 153:1259-64. Med 2006; 4: 486-93.

Pleis, J.R., Lucas, J.W., Ward, B.W. 2009. Summary health statistics for U.S. adults: National Health Interview Survey, 2008. National Center for Health Statistics. Vital Health Stat., 10. (242):1-157

Ray, N.F., Baraniuk, I.N., Thamer, M., et al. 1996. Healthcare expenditures for sinusitis in 1996: contributions of asthma, rhinitis, and other airway disorders. J. Allergy Clin. Immunol., 103408-414.414 .
Rosenfeld, R.M., Andes, D., Bhattacharyya, N., Cheung, D., Eisenberg, S., Ganiats, T.G., Gelzer, A., Hamilos, D., Haydon, R.C., Hudgins, P.A., Jones, S., 2007. "Clinical practice guideline: adult sinusitis". Otolaryngology--head and neck surgery: official J. American Academy of Otolaryngology-Head and Neck Surgery, 137 (3 Suppl): S131. doi:10.1016/j.otohns. 2007.06.726. PMID 17761281.

Rosenfeld, R.M., Piccirillo, J.F., Chandrasekhar, S.S., Brook, I., Ashok Kumar, K., Kramper, M., Orlandi, R.R., Palmer, J.N., Patel, Z.M., Peters, A., Walsh, S.A. Corrigan, MD (April 2015). "Clinical practice guideline (update): adult sinusitis executive summary.". Otolaryngology--head and neck surgery: official J. American Academy of Otolaryngology-Head and Neck Surgery. 152 (4): 598-609.

doi:10.1177/01945998 15574247.

Savolainen, S., Jousimies-Somer, H., Karjalainen, J., Ylikoski, J. Do simple laboratory tests help in etiologic diagnosis in acute maxillary sinusitis? Acta Otolaryngol. Suppl., 529: 144-147.

Shah, A.R., Hairston, J.A., Tami, T.A. 2005. Sinusitis in HIV: microbiology and therapy. Curr. Allergy Asthma Rep., 5(6):495-9.

Smith, W.M., Davidson, T.M., Murphy, C. 2003. Regional variations in chronic rhinosinusitis, Otolayrn Head Neck Surg., 141(3): 347-52.

Sunali, S., Khanna and A.S. Gharpure. 2012. Correlation of increased sinusitis and urban air pollution, Ind. J. Sci. Res. and Tech.,1(1): 14-17. ISSN:-2321-9262 (Online) Online Available at: http://www.indjsrt.com Research Article 14.

\section{How to cite this article:}

Gowri, S., and Kanaga Priya Muthiah. 2017. Diagnostic Utility of serum C - ReactiveProtein in Rhinosinusitis and its Role in Reducing Antibiotic Use. Int.J.Curr.Microbiol.App.Sci. 6(1): 761-766. doi: http://dx.doi.org/10.20546/ijcmas.2017.601.091 